\title{
NANOHIDROGEL TAPIOKA MENGGUNAKAN EPIKLOROHIDRIN SEBAGAI AGEN PENGIKAT SILANG
}

\section{NANO - TAPIOCA HYDROGELS USING EPICHLOROHIDRIN AS CROSSLINKING AGENT}

\author{
Mersi Kurniati $^{1{ }^{*}}$, Christina Winarti ${ }^{2)}$, Firda Aulya Syamani ${ }^{3)}$, Indah Puspita ${ }^{1)}$ \\ ${ }^{1)}$ Divisi Biofisika Departemen Fisika Institut Pertanian Bogor, \\ Jln Meranti, Kampus IPB Dramaga, Bogor, 16680 \\ Email: mersikurniati@gmail.com \\ ${ }^{2)}$ Balai Besar Penelitian dan Pengembangan Pasca Panen Pertanian \\ ${ }^{3}$ Pusat Penelitian Biomaterial, LIPI
}

Makalah: Diterima 4 September 2018; Diperbaiki 20 April 2019; Disetujui 10 Mei 2019

\begin{abstract}
Natural polymer-based nanohydrogel, like starches, promises superior properties such as more ecofriendly, and cheaper prices because their raw materials are available naturally in abundant quantities compared to synthetic polymers. To obtain synthetic approaching characteristics, natural polymers need to be modified to improve their mechanical stability. Research has been conducted to develop the hydrogel prepared from acid hydrolysed starch for 2 hours and 24 hours. The process of synthesising nanoparticles from hydrolyzed tapioca starch was done through the precipitation of ethanol. Synthesis of nanohydrogel was conducted by crosslinking methods using epichlorohydrin (Ech.) 5, 10, and 20\%. Result showed that the particle size of tapioca nanohydrogel ranging from $14.97-492.7 \mathrm{~nm}$. The most optimum treatment was nanohidrogel resulted from 2 hours hydrolyzed tapioca with 5\% Ech. concentration, resulting swelling power, gel fraction, and texture of $357.02 \%, 77,71 \%$, and $5.61 \mathrm{~mJ}$, respectively. Nanohydrogel is promising material as carrier matrix for agrochemical as well as fertilizer.
\end{abstract}

Keywords : epichlorohydrin, nanohydrogel, tapioca

\section{ABSTRAK}

Nanohidrogel berbahan dasar polimer alam, seperti pati, menjanjikan sifat yang lebih unggul, yaitu lebih ramah lingkungan dan bahan bakunya dapat diperbarui serta harganya lebih murah karena tersedia secara lokal dalam jumlah yang cukup melimpah dibandingkan polimer sintetis. Guna mendapatkan karakteristik yang mendekati polimer sintetis, polimer alam perlu dimodifikasi. Telah dilakukan penelitian untuk mengembangkan nanohidrogel berbasis tapioka yang dimodifikasi menjadi partikel berukuran nano dengan hidrolisis asam selama 2 jam dan 24 jam dan presipitasi etanol. Selanjutnya proses pembentukan gel dilakukan dengan penambahan epiklorohidrin sebagai agen pengikat silang. Hasil penelitian menunjukkan bahwa ukuran partikel nanohidrogel tapioka antara 14,97 - 492,7 nm. Nanohidrogel hidrolisis 2 jam dan konsentrasi epiklohidrin $5 \%$ memberikan hasil optimum untuk karakteristik fisik dan mekanik dengan kemampuan mengembang sebesar $357,02 \%$, fraksi gel $77,71 \%$, dan kekerasan 5,61 mJ. Nanohidrogel yang dihasilkan potensial digunakan untuk pembawa bahan agrokimia dan pupuk.

Kata kunci : epiklorohidrin, nanohidrogel, tapioca

\section{PENDAHULUAN}

Hidrogel adalah polimer berstruktur tiga dimensi yang memiliki kemampuan menyerap air yang sangat tinggi (Kalhapure et al., 2016). Hidrogel umunya disintesis menggunakan bahan polimer sintetis atau kombinasi dari polimer sintetis dan alami (Akhtar et al., 2015). Penggunaan polimer sintetik kurang ramah lingkungan karena sulit terurai dialam. Selain itu, ketersediaan polimer sintetis juga terbatas dan harganya cukup tinggi. Oleh sebab itu, penelitian ini menggunakan polimer alami yang jumlahnya melimpah dialam, dapat diperbaharui, dan harganya lebih murah.

Penggunaan hidrogel berbasis polisakarida alami menarik perhatian banyak peneliti karena sejumlah kelebihan diantaranya murah, biodegradable, cukup kuat, densitas rendah, sifat termal yang baik, dapat digunakan kembali, tidak berisiko terhadap kesehatan dan hemat energi (Thakur et al., 2013a dan 2013b; Thakur et al., 2014). Hidrogel berbasis pati menarik perhatian lebih besar karena efektif secara ekonomis dan mudah dimodifikasi dengan pencangkokan monomer vinil. Gugus $\mathrm{OH}$ dalam pati berpotensi untuk membentuk jaringan kompleks copolimer yang akan meningkatkan kemampuan penyerapan air secara nyata (Zhang et al., 2013).

Salah satu pati yang angka produksinya tinggi di Indonesia adalah pati yang diperoleh dari ubi kayu (singkong). Berdasarkan data Badan Pusat Statistik (BPS) pada tahun 2016, produksi ubi kayu 
mencapai angka 20744674 ton. Akan tetapi, polimer alam seperti pati cenderung mudah terdegradasi dan memiliki kestabilan mekanik yang rendah (Garcia et al., 2011). Oleh sebab itu perlu dilakukan modifikasi untuk memperoleh polimer yang memiliki sifat mendekati polimer sintetik.

Modifikasi dapat dilakukan dengan memperkecil ukuran partikel pati menjadi berukuran nano. Ukuran partikel nano yang sangat kecil menyebabkan perbandingan luas permukaan terhadap volume menjadi semakin besar, sehingga partikel tersebut semakin reaktif dan lebih tahan terhadap keadaan termal (Suwarda dan Maarif, 2013). Hidrogel dengan struktur nano (nanohidrogel memiliki kelebihan diantaranya lebih cepat dalam merespon perubahan lingkungan dibandingkan dalam bentuk makro (bulk). Hal tersebut disebabkan area antarmuka yang jauh lebih besar per unit massa, kecepatan tukar (exchange rate) yang lebih tinggi, kecepatan respon yang lebih tinggi terhadap stimulus eksternal seperti $\mathrm{pH}$ dan kekuatan ionic (Sahiner et al., 2006).

Partikel tapioka dapat diperkecil menjadi ukuran nano melalui proses hidrolisis asam dan metode presipitasi etanol. Proses hidrolisis asam merupakan preparasi awal tapioka. Proses ini dilakukan untuk memutus fraksi amilosa rantai panjang dan titik percabangan amilopektin, sehingga dihasilkan pati dengan jumlah amilosa rantai pendek yang lebih tinggi (Winarti, 2014). Untuk pembentukan hidrogel diperlukan penambahan agen pengikat silang kimia sebagai inisiator reaksi pengikatan silang (Ghanbarzadeh et al., 2011).

Epiklorohidrin merupakan salah satu agen pengikat silang yang umum digunakan dalam modifikasi pati. Reaksi epiklorohidrin dan pati menghasilkan pati yang tahan terhadap perubahan $\mathrm{pH}$ dan membentuk ikatan eter antar ikatan gugus hidroksil pada pati (Ackar et al., 2010). Proses pengikatan silang menguatkan ikatan hidrogen pada molekul pati, sehingga meningkatkan sifat mekanik dan ketahanan pati terhadap perubahan suhu (Kittipongpatana dan Kittipongpatana, 2013). Penelitian ini dilakukan untuk mendapatkan nanohidrogel berbahan dasar tapioka nano partikel yang bersifat mendekati hidrogel yang dihasilkan dari polimer sintetis.

\section{BAHAN DAN METODE}

\section{Bahan}

Bahan yang digunakan dalam penelitian ini diantaranya tapioka, akuades, epiklorohidrin, etanol 95\%, larutan asam klorida $(\mathrm{HCl}) 2,2 \mathrm{~N}, \mathrm{NaOH} 5 \%$.

\section{Alat}

Alat yang digunakan dalam penelitian ini diantaranya neraca analitik AND HR-250A, gelas beker IWAKI Asahi Glass $500 \mathrm{~mL}$, hotplate stirrer Wisd Laboratory Instruments, Particle Size Analyzer (PSA) Malvern, Scanning Electron Microscopy
(SEM) Zeiss EVO MA10, dan Texture Analyzer TexturePro CT V1.2 Build 9.

\section{Hidrolisis Pati}

Hidrolisis pati dilakukan menggunakan metode yang dimodifikasi dari Faridah et al. (2010). Pati singkong (tapioka) dibuat suspensi dalam larutan $\mathrm{HCl}$ konsentrasi 2,2 N, dengan perbandingan 1:2 (b/v). Suspensi lalu direndam selama 2 jam dan 24 jam pada suhu sekitar $35-55^{\circ} \mathrm{C}$. Selanjutnya dilakukan penetralan dengan penambahan $\mathrm{NaOH}$ konsentrasi 5\%. Pati yang telah dinetralkan kemudian disaring lalu dikeringkan dalam oven pada suhu $55^{\circ} \mathrm{C}$.

\section{Produksi Pati Nanopartikel}

Pati nanopartikel diproduksi menggunakan metode presipitasi etanol yang diadaptasi dari Ma $e t$ al. (2008). Pati terhidrolisis dilarutkan dalam akuades dengan rasio 1:10 (b/v). Selanjutnya dipanaskan sambil diaduk menggunakan magnetic stirrer pada suhu $85^{\circ} \mathrm{C}$ hingga mengalami gelatinisasi. Setelah itu, dilakukan pendinginan suspensi pada suhu ruang sambil ditambahkan etanol konsentrasi 95\% secara perlahan - lahan hingga jumlah etanol yang ditambahkan sama dengan jumlah pelarut pati. Suspensi kemudian dicuci menggunakan etanol untuk menghilangkan air. Selanjutnya dilakukan penyaringan dan pengeringan, sehingga dihasilkan pati nanopartikel.

\section{Sintesis Nanohidrogel}

Sintesis nanohidrogel dimodifikasi dari Ghanbarzadeh et al. (2011). Tapioka nanopartikel didispersikan dengan akuades dengan perbandingan 1:4 (b/v). Selanjutnya suspensi diaduk sambil dipanaskan hingga suhu $55^{\circ} \mathrm{C}$ hingga homogen dan dilakukan penambahan epiklorohidrin sebagai agen pengikat silang dengan variasi komposisi 5\%, 10\%, dan $20 \%$ dari massa kering pati nanopartikel yang digunakan. Suspensi diaduk hingga homogen selama satu jam dan didiamkan pada suhu ruang selama 4 jam hingga membentuk endapan. Endapan yang dihasilkan disaring dan dikeringkan dengan oven pada suhu $60^{\circ} \mathrm{C}$. Hasil akhir berupa polimer yang sudah kering atau nanohidrogel. Perlakuan dalam penelitian ini adalah perbedaan proses hidrolisis asam, yaitu 2 jam dan 24 jam, serta konsentrasi epiklorohidrin yaitu 5, 10, dan 20\%. Percobaan dilakukan dengan tiga kali ulangan.

\section{Pengujian Kemampuan Swelling}

Kemampuan swelling adalah kemampuan mengembang nanohidrogel pada saat menyerap air. Swelling diperoleh dengan mengukur rasio massa sampel setelah direndam dalam air $\left(m_{s}\right)$ terhadap massa awal sampel $\left(\mathrm{m}_{\mathrm{k}}\right)$. Penentuan massa nanohidrogel dilakukan menggunakan metode gravimetri. Sebelum penimbangan nanohidrogel yang telah mengalami perendaman, dilakukan 
penghilangan sisa - sisa air dengan cara menempelkan kertas saring pada permukaan nanohidrogel. Persentase swelling dapat dihitung dengan persamaan berikut:

$$
\text { Swelling }(\%)=\frac{\mathrm{m}_{\mathrm{s}}}{\mathrm{m}_{\mathrm{k}}} \times 100 \%
$$

\section{Pengujian Kandungan Gel (Fraksi Gel)}

Pengujian fraksi gel yang dilakukan mengacu pada Erizal et al. (2012). Nanohidrogel yang telah dikeringkan ditimbang $\left(\mathrm{m}_{\mathrm{k}}\right)$, selanjutnya direndam dalam air selama 24 jam lalu dikeringkan dengan oven pada suhu $60^{\circ} \mathrm{C}$ selama 6 jam. Selanjutnya dilakukan penimbangan terhadap massa kering setelah perendaman $\left(\mathrm{m}_{\mathrm{g}}\right)$. Fraksi gel dapat ditentukan dengan persamaan berikut:

$$
\text { Fraksi Gel }(\%)=\frac{m_{\mathrm{g}}}{\mathrm{m}_{\mathrm{k}}} \times 100 \%
$$

\section{HASIL DAN PEMBAHASAN}

\section{Tapioka Nanopartikel}

Tapioka terlebih dahulu dihidrolisis menggunakan asam klorida 2,2 $\mathrm{N}$ selama 2 jam dan 24 jam. Proses hidrolisis berperan sebagai pemutus fraksi amilosa rantai panjang dan titik percabangan

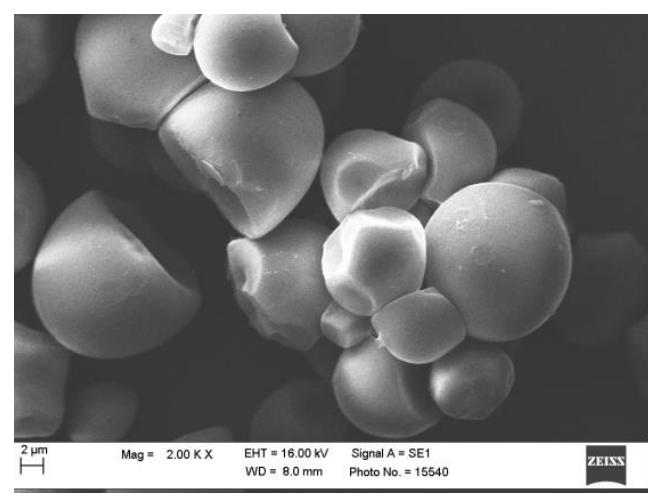

(a) amilopektin, sehingga dihasilkan tapioka dengan jumlah amilosa rantai pendek yang lebih tinggi (Pudjiastuti, 2010). Asam klorida ( $\mathrm{HCl})$ selama proses hidrolisis mendegradasi daerah amorf yang terdapat pada granula pati, sehingga permukaan granula pati tidak mengalami perubahan bentuk secara signifikan seperti yang terlihat pada Gambar 1 (Ferrini et al., 2008).

Selanjutnya dilakukan produksi pati nanopartikel menggunakan metode presipitasi etanol. Setelah pati dihidrolisis, pati digelatinisasi kemudian ditetesi etanol secara perlahan - lahan untuk menghasilkan pati berukuran nano meter (Ma et al., 2008). Hasil distribusi ukuran partikel menggunakan PSA yang ditunjukkan pada Gambar 2 dan Gambar 3 menunjukkan tapioka yang dihasilkan pada penelitian ini sudah berukuran nano. Hasil menunjukkan pati nanopartikel dari tapioka terhidrolisis 2 jam berada pada rentang ukuran 15,97 nm sampai 492,7 nm dengan ukuran paling dominan pada 33,04 nm. Sementara itu, untuk pati nanopartikel dari pati yang dihidrolisis selama 24 jam memiliki ukuran partikel yang berada pada rentang 35,53 nm sampai 450,2 $\mathrm{nm}$ dengan ukuran yang paling dominan pada $35,53 \mathrm{~nm}$.

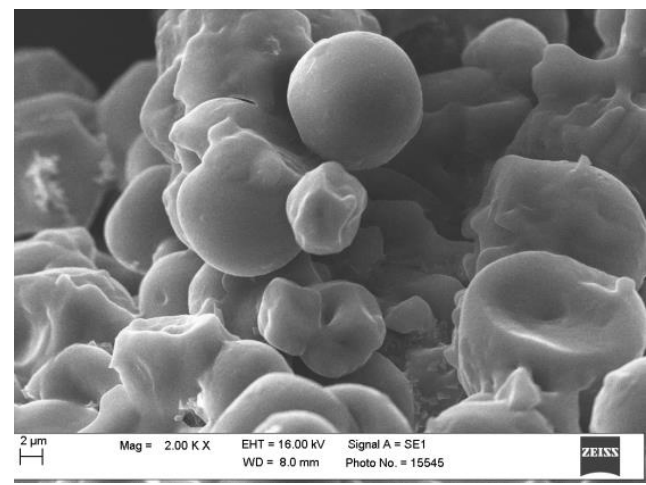

(b)

Gambar 1. Morfologi tapioka terhidrolisis (a) 2 jam dan (b) 24 jam pada perbesaran 2000 kali

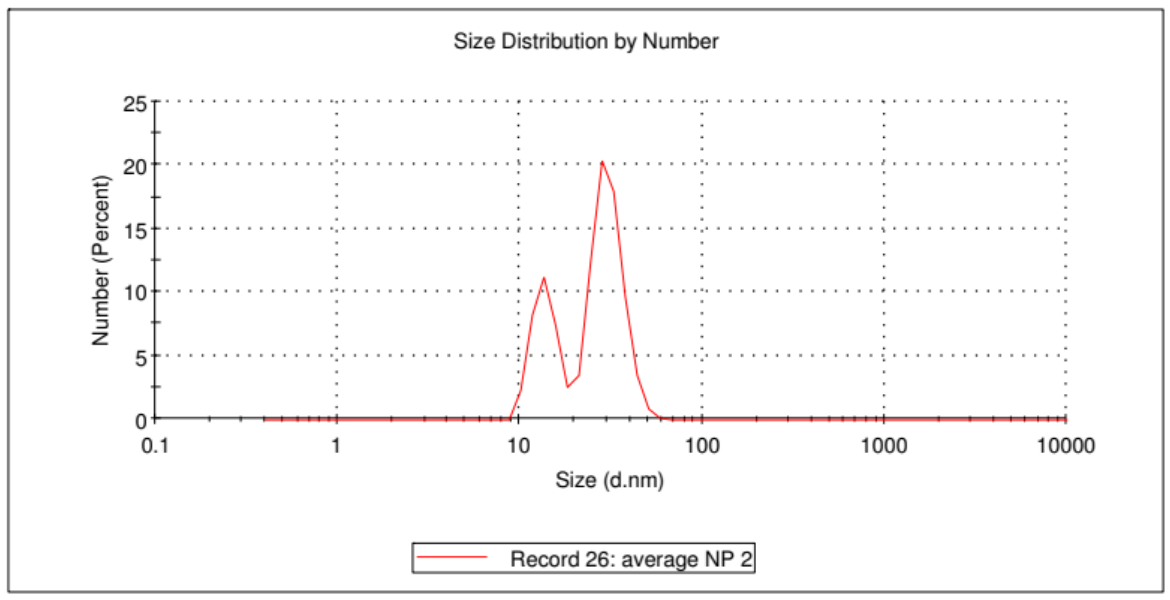

Gambar 2. Distribusi ukuran partikel nano tapioka dari tapioka terhidrolisis 2 jam 


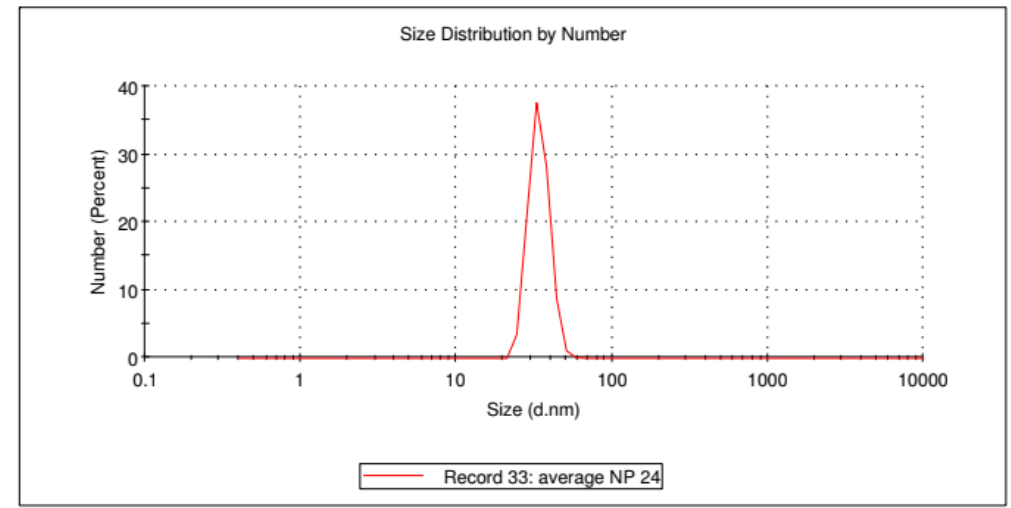

Gambar 3. Distribusi ukuran partikel nano tapioka dari tapioka terhidrolisis 24 jam

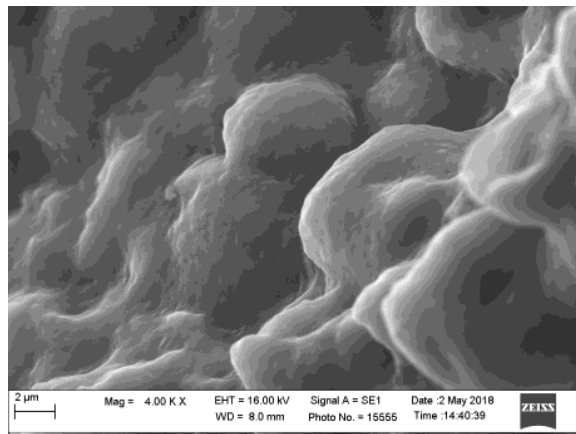

(a)

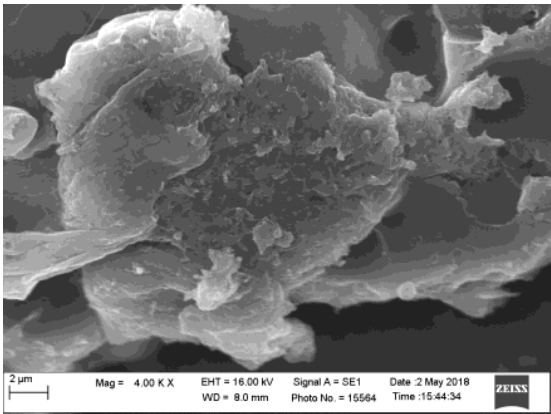

(b)

Gambar 4. Morfologi nanopartikel tapioka terhidrolisis (a)2 jam dan (b) 24 jam pada perbesaran 4000 kali

Hasil pengukuran PSA menunjukkan tapioka yang dihasilkan memiliki keragaman ukuran partikel yang tinggi. Hal ini disebabkan tapioka nanopartikel yang dihasilkan dari presipitasi belum terpisah secara sempurna dan masih berkumpul membentuk aglomerasi (Winarti et al., 2014). Hasil ini juga didukung oleh penampakan morfologi nanopartikel yang dihasilkan menggunakan SEM seperti yang ditunjukkan pada Gambar 4. Berdasarkan Gambar 4, terlihat bahwa nanopartikel yang dihasilkan dari tapioka terhidrolisis 24 jam (Gambar 4b) memiliki pori - pori yang lebih banyak dibandingkan nanopartikel yang dihasilkan dari tapioka yang terhidrolisis 2 jam (Gambar 4b). Hal ini disebabkan nanopartikel yang dihasilkan tapioka terhidrolisis 24 jam belum terpisah secara sempurna, sehingga tidak terlihat perbedaan ukuran yang signifikan antara nanopartikel yang dihasilkan dari tapioka terhidrolisis 2 jam dan 24 jam (Miao et al., 2011).

\section{Kemampuan Mengembang (Swelling)}

Hasil analisis swelling nanohidrogel ditunjukkan pada Gambar 5, 6, dan 7. Gambar 5 dan Gambar 6 menunjukkan kinetika swelling nanohidrogel tapioka selama 1 jam yang diukur setiap 10 menit. Hasil menunjukkan nanohidrogel tapioka terhidrolisis 2 jam (Gambar 5) mengalami peningkatan swelling yang lebih signifikan dibandingkan nanohidrogel tapioka yang terhidrolisis 24 jam (Gambar 6).
Hasil kinetika swelling tersebut juga didukung dengan data pada Gambar 7. Berdasarkan Gambar 7, penambahan konsentrasi epiklorohidrin menyebabkan kemampuan nanohidrogel dalam menyerap air berkurang. Penambahan Epiklorohidrin menyebabkan gugus $\mathrm{OH}$ yang bersifat hidrofilik mengalami pengikatan silang dan membentuk gugus ester yang hidrofobik (Ma et al., 2008). Akibatnya, penambahan epiklorohidrin mengurangi swelling pada nanohidrogel seperti yang ditunjukkan pada nanohidrogel seperti yang ditunjukkan pada Gambar 7.

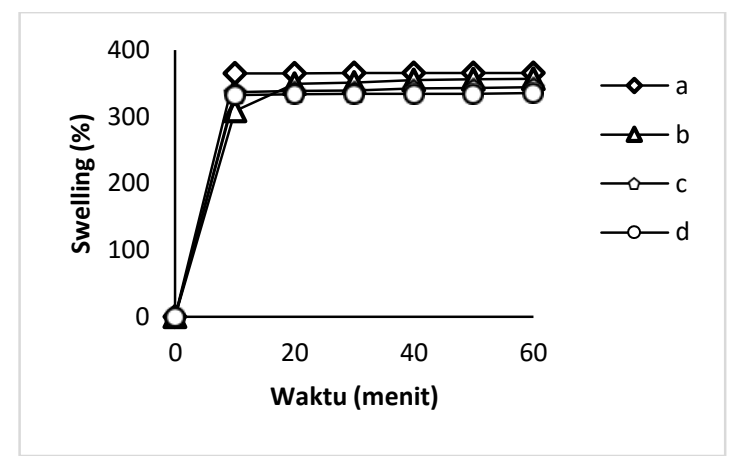

Gambar 5. Hubungan swelling nanohidrogel tapioka terhidrolisis 2 jam (a) kontrol, (b) konsentrasi epiklorohidrin 5\%, (c) konsentrasi epiklorohidrin $10 \%$, dan (d) konsentrasi epiklorohidrin 20\% terhadap waktu perendaman 
Akan tetapi, pengikatan silang pada tapioka memperkuat ikatan antarmolekul dengan terbentuknya ikatan kovalen yang dapat menyebabkan meningkatnya kekuatan fisik nanohidrogel (Ghanbarzadeh et al., 2011). Selain itu, pengikatan silang juga dapat menghasilkan struktur tiga dimensi yang menurunkan kelarutan nanohidrogel di dalam air, sehingga nanohidrogel lebih mampu mempertahankan bentuknya dan tidak mudah mengalami degradasi.

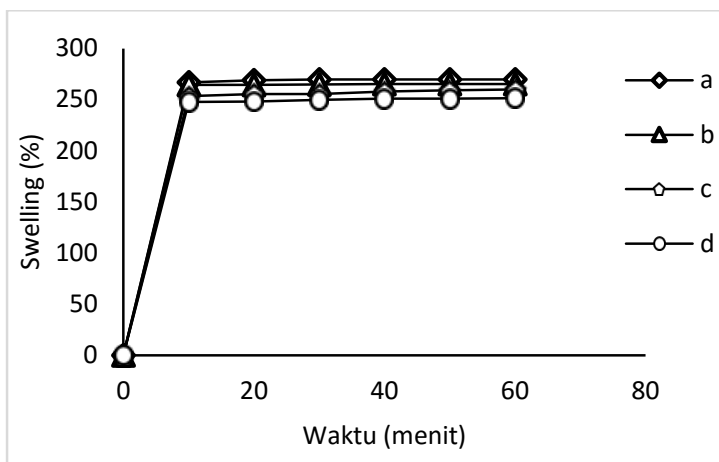

Gambar 6. Hubungan swelling nanohidrogel tapioka terhidrolisis 24 jam (a) kontrol, (b) konsentrasi epiklorohidrin 5\%, (c) konsentrasi epiklorohidrin $10 \%$, dan (d) konsentrasi epiklorohidrin $20 \%$ terhadap waktu perendaman

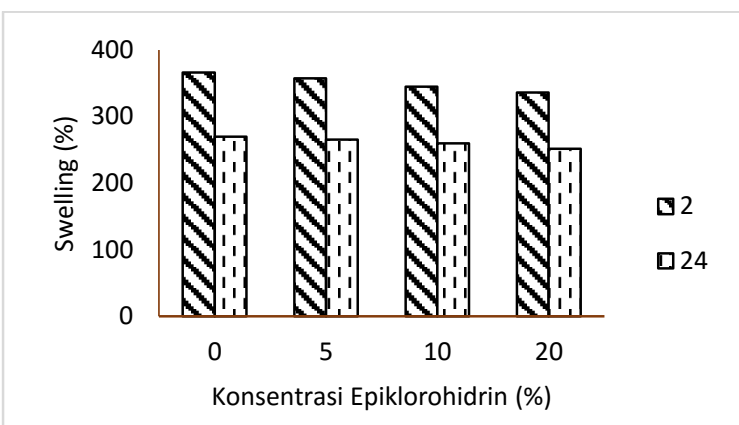

Gambar 7. Pengaruh konsentrasi epiklorohidrin dan waktu hidrolisis terhadap swelling nanohidrogel

Selain pengaruh konsentrasi epiklorohidrin terhadap swelling nanohidrogel, Gambar 7 juga menunjukkan pengaruh lamanya waktu hidrolisis terhadap kemampuan swelling nanohidrogel. Nanohidrogel yang disintesis dari tapioka yang dihidrolisis selama 2 jam menunjukkan kemampuan swelling yang lebih tinggi dibandingkan nanohidrogel yang disintesis dari tapioka yang dihidrolisis selama 24 jam. Lamanya waktu hidrolisis mempengaruhi kristalinitas pati nanopartikel yang dihasilkan. Semakin lama waktu hidrolisis pati, bagian amorf pada lamela pati akan semakin banyak yang mengalami degradasi (Szymonska et al., 2009). Hal ini disebabkan pada proses hidrolisis asam, bagian yang terlebih dahulu diserang adalah bagian amorf, sehingga pada waktu hidrolisis 24 jam, bagian amorf telah terdegradasi dan menyisakan bagian kristalin (Winarti et al., 2014). Bagian amorf pada granula pati cenderung tersusun oleh amilosa, sementara amilopektin yang memiliki struktur double heliks umumnya berada pada daerah kristalin pati. Terdegradasinya bagian amorf pati menyebabkan berkurangnya jumlah amilosa yang terdapat dalam granula pati. Akibatnya swelling berkurang, karena bagian yang berperan dalam swelling pati adalah amilosa (Corre et al., 2010).

\section{Fraksi Gel}

Hasil pengukuran fraksi gel pada Gambar 8 menunjukkan semakin tinggi konsentrasi epiklorohidrin yang ditambahkan, semakin tinggi fraksi gel yang dihasilkan. Nilai fraksi gel merupakan bagian yang tidak larut selama proses perendaman yang menunjukkan efisiensi proses pengikatan silang (Erizal et al., 2013). Meningkatnya nilai fraksi gel setelah diberikan epiklorohidrin mengindikasikan bahwa terjadi pengikatan silang antar rantai polimer. Hal ini menyebabkan gaya antar molekul didalam nanohidrogel semakin kuat, sehingga nanohidrogel ini tidak mudah terlarut dalam air dan kekuatan mekaniknya semakin baik (Erizal et al., 2012),

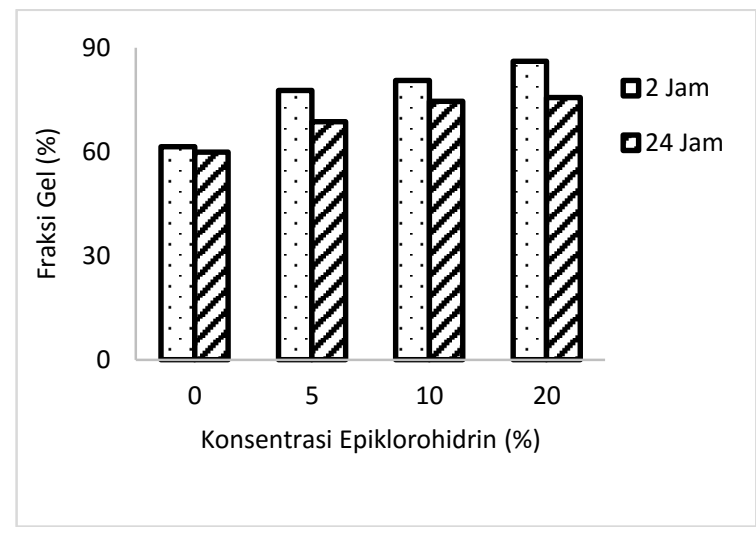

Gambar 8. Pengaruh konsentrasi epiklorohidrin dan waktu hidrolisis terhadap fraksi gel nanohidrogel

\section{Analisis Tekstur}

Pengukuran tekstur nanohidrogel dilakukan menggunakan instrumen texture analyzer. Hasil tekstur yang diperoleh disajikan dalam Tabel 1 . Berdasarkan Tabel 1, dapat diketahui bahwa penambahan agen pengikat silang berupa epiklorohidrin meningkatkan hardness, cohesiveness, dan springiness, serta menurunkan adhesiveness. Menurut Ghanbarzadeh et al. (2011), reaksi ikatan silang pada nanohidrogel menyebabkan terbentuknya ikatan antar molekul polimer. Hal ini menyebabkan kekuatan nanohidrogel akan 
meningkat seiring dengan meningkatnya konsentrasi agen pengikat silang. Pada Tabel 1, nilai kekerasan nanohidrogel meningkat diakibatkan penambahan agen pengikat silang (epiklorohidrin) dengan konsentrasi 5\%, 10\%, dan 20\%.

Selain reaksi pengikatan silang, kekerasan nanohidrogel juga meningkat seiring dengan bertambahnya waktu hidrolisis pati, seperti yang ditunjukkan pada Tabel 1. Pada perlakuan crosslinking yang sama, sampel dengan kode 24 (nanohidrogel dari tapioka terhidrolisis 24 jam) menunjukkan kekerasan yang lebih tinggi dibandingkan dengan nilai kekerasan sampel kode 2 (nanohidrogel dari tapioka terhidrolisis 2 jam). Hidrolisis asam menyebabkan terdegredasinya rantai - rantai amilosa dan percabangan amilopektin yang terdapat pada daerah amorf dan menyisakan daerah kristalin, karena asam menyerang daerah kristalin secara lambat berbeda dengan daerah amorf yang lebih cepat diserang (Corre et al., 2010). Terdegradasinya daerah amorf pada granula pati menyebabkan ukuran partikel pati menjadi lebih kecil (Srichuwong et al., 2005). Kecilnya ukuran partikel menyebabkan pati lebih mudah untuk bereaksi dan membentuk ikatan silang. Hal inilah yang menyebabkan kekerasan pada nanohidrogel dari tapioka yang dihidrolisis 24 jam lebih tinggi dibandingkan dengan kekerasan nanohidrogel yang dihasilkan dari tapioka yang dihidrolisis 2 jam pada perlakuan crosslinking yang sama. Selain itu, penambahan agen pengikat silang juga dapat meningkatkan nilai cohesiveness dan menurunkan nilai adhesiveness.

Adhesiveness merupakan suatu ukuran yang menggambarkan gaya antar molekul yang tidak sejenis (Hurler et al., 2012). Semakin besar nilai adhesiveness, maka suatu material akan memiliki tekstur yang mudah melekat pada medium. Tabel 1 menunjukan perlakuan kontrol (2A dan 24A) mempunyai nilai adhesiveness yang sangat tinggi jika dibandingkan dengan nanohidrogel yang telah mengalami ikatan silang. Tingginya adhesiveness menyebabkan sampel kontrol memiliki struktur yang lengket. Adhesiveness yang semakin tinggi menyebabkan nanohidrogel lebih mudah terdegradasi. Tabel 1 menunjukkan pemberian perlakuan ikatan silang menggunakan epiklorohidrin menurunkan adhesiveness secara signifikan dan meningkatkan cohesiveness. Sementara itu, cohesiveness seperti yang ditunjukkan pada Tabel 1 memiliki hubungan yang berkebalikan dengan adhesiveness. Semakin rendah nilai adhesiveness nanohidrogel, maka semakin tinggi cohesiveness nanohidrogel. Cohesiveness merupakan suatu ukuran yang menggambarkan kuatnya interaksi antar molekul yang sejenis. Semakin tinggi nilai cohesiveness, maka kestabilan mekaniknya akan semakin baik.

Springiness merupakan ukuran yang menunjukkan tingkat elastisitas suatu bahan apabila diberikan beban. Nilai ini dapat diukur dengan mengukur gaya pemulihan yang dimiliki oleh bahan setelah diberikan gaya kompresi. Berdasarkan Tabel 1, nanohidrogel yang memiliki nilai springiness tertinggi adalah nanohidrogel dengan kode sampel 2C5 yang merupakan nanohidrogel yang disintesis dari pati yang dihidrolisis selama 2 jam dengan penambahan epiklorohidrin sebanyak 5\%. Hal ini menunjukkan sampel 2C5 merupakan nanohidrogel yang memiliki tingkat elastisitas tertinggi dibandingkan dengan perlakuan lainnya. Namun, apabila dilihat secara keseluruhan, pada perlakuan crosslinking yang sama, nanohidrogel yang disintesis dari pati yang dihidrolisis selama 2 jam memiliki tingkat elastisitas lebih tinggi dibandingkan nanohidrogel dari pati yang dihidrolisis selama 24 jam. Hal ini disebabkan nanohidrogel memiliki struktur yang lebih rigid akibat ikatan silang yang terbentuk lebih rapat, sehingga kemampuan untuk kembali ke bentuk semula setelah menerima beban semakin rendah.

Tabel 1. Hasil analisis tekstur nanohidrogel pada berbagai perlakuan

\begin{tabular}{lrccc}
\hline Kode & $\begin{array}{c}\text { Hardness } \\
(\mathrm{mJ})\end{array}$ & Adhesiveness $(\mathrm{mJ})$ & Cohesiveness & Springiness $(\mathrm{mm})$ \\
\hline $2 \mathrm{~A}$ & 2,36 & 2,00 & 0,05 & 0,07 \\
$2 \mathrm{C} 5$ & 5,61 & 0,19 & 0,13 & 3,66 \\
$2 \mathrm{C} 1$ & 10,66 & 0,11 & 0,21 & 3,39 \\
$2 \mathrm{C} 2$ & 13,56 & 0,08 & 0,32 & 2,84 \\
$24 \mathrm{~A}$ & 4,03 & 1,70 & 0,03 & 0,16 \\
$24 \mathrm{C} 5$ & 8,50 & 0,06 & 0,30 & 2,56 \\
$24 \mathrm{C} 1$ & 12,84 & 0,05 & 0,32 & 2,89 \\
$24 \mathrm{C} 2$ & 15,80 & 0,04 & 0,33 & 2,81 \\
\hline
\end{tabular}

2: hidrolisis 2 jam; 24:hidrolisis 24 jam; A: kontrol; C5:konsentrasi epiklorohidrin 5\%; C1:konsentrasi epiklorohidrin 10\%; C2:konsentrasi epiklorohidrin $20 \%$ 


\section{Analisis Morfologi}

Morfologi permukaan nanohidrogel diamati menggunakan Scanning Electron Microscopy (SEM). Hasil SEM nanohidrogel disajikan pada Gambar 9. Berdasarkan hasil morfologi yang diperoleh, semakin banyak epiklorohidrin yang ditambahkan, permukaan nanohidrogel terlihat semakin halus. Hal ini disebabkan semakin banyak agen pengikat silang maka ikatan yang terbentuk antar rantai polimer semakin rapat. Bertambahnya ikatan antar rantai polimer akan menutup sebagian pori yang terdapat pada nanohidrogel. Hasil ini sejalan dengan hasil swelling yang diperoleh bahwa semakin tinggi konsentrasi epiklorohidrin, swelling nanohidrogel berkurang. Akan tetapi, penambahan epiklorohidrin menyebabkan ketahanan nanohidrogel dalam mencegah deformasi semakin baik karena proses pengikatan silang secara kimia menyebabkan rantai - rantai polimer yang ada pada tapioka nanopartikel saling bertautan untuk membentuk struktur tiga dimensi (Ghanbarzadeh et al. 2011).

Hasil citra SEM yang ditunjukkan oleh Gambar 9 juga menunjukkan nanohidrogel yang dihasilkan dari proses hidrolisis 2 jam memiliki pori yang lebih banyak dibandingkan nanohidrogel yang dihasilkan dari tapioka terhidrolisis 24 jam. Hasil ini sesuai dengan hasil kemampuan swelling. Nanohidrogel dari tapioka terhidrolisis 2 jam memiliki kemampuan swelling yang lebih tinggi dibandingkan nanohidrogel dari tapioka terhidrolisis 24 jam. Pori nanohidrogel yang lebih banyak akan memudahkan penetrasi air untuk masuk kedalamnya, sehingga dapat meningkatkan kemampuan swelling nanohidrogel (Annabi et al., 2010).

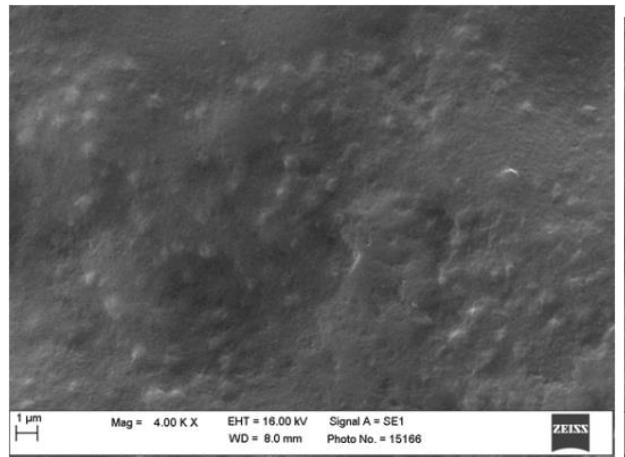

(a)

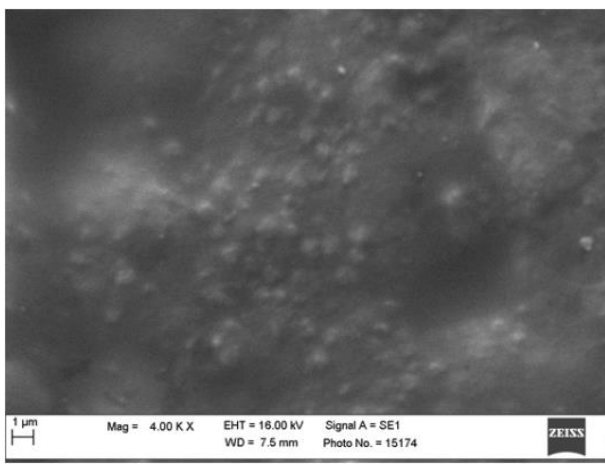

(c)

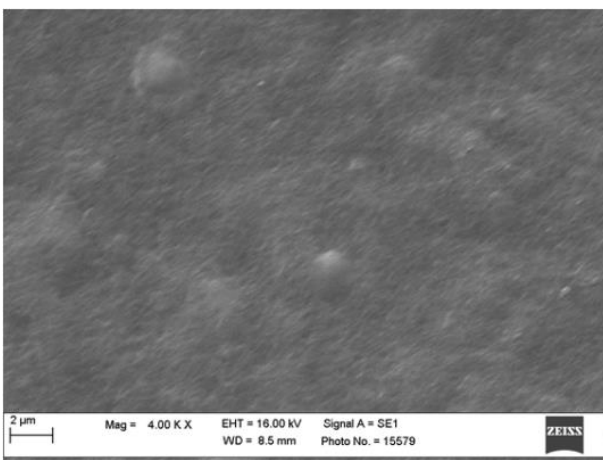

(e)

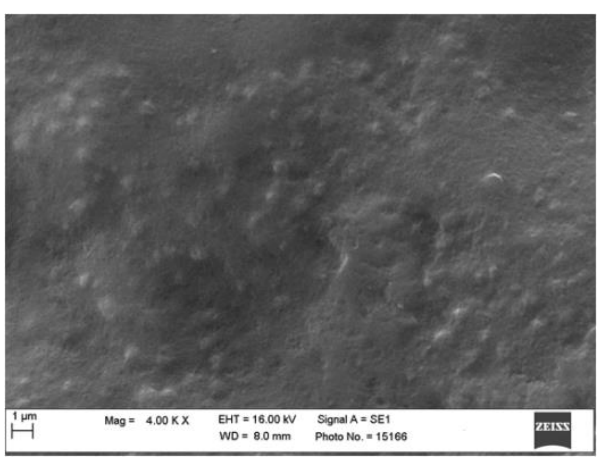

(b)

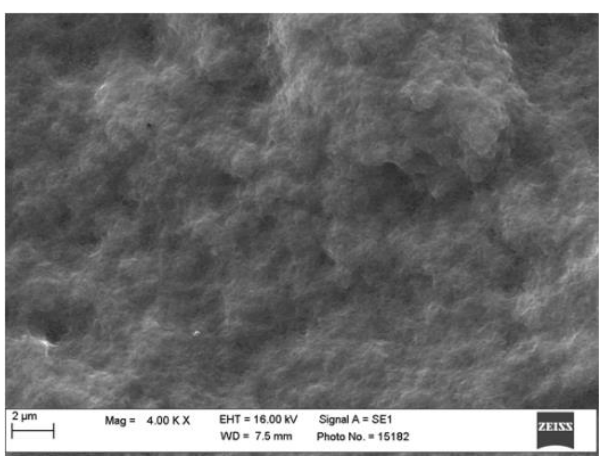

(d)

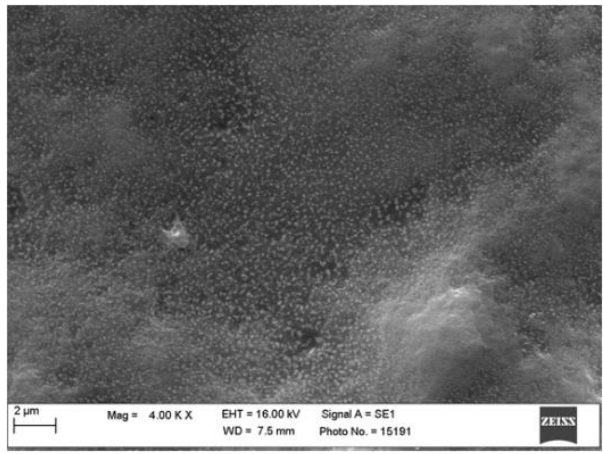

(f) 


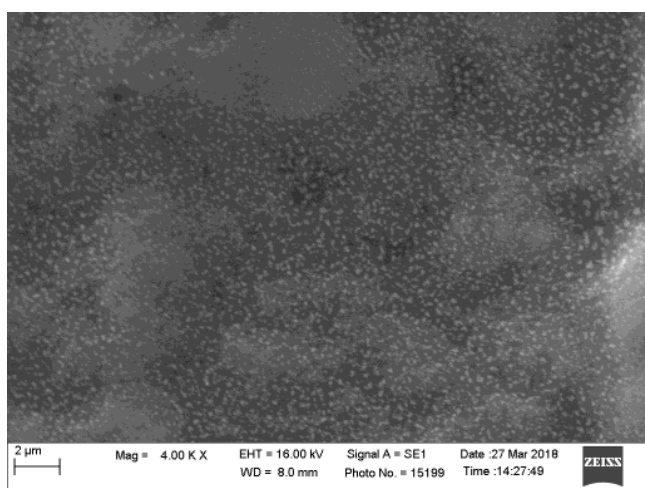

(g)

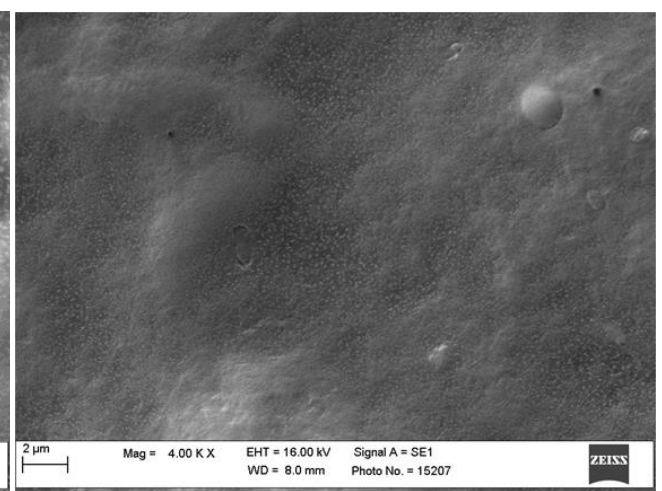

(h)

Gambar 9. Morfologi nanohidrogel dari pati terhidrolisis 2 jam (a) kontrol, (b) konsentrasi epiklorohidrin 5\%, (c) konsentrasi epiklorohidrin 10\%, (d) konsentrasi epiklorohidrin 20\%; dan dari pati terhidrolisis 24 jam (e) kontrol, (f) konsentrasi epiklorohidrin 5\%, (g) konsentrasi epiklorohidrin 10\%, (h) konsentrasi epiklorohidrin $20 \%$

\section{Kesimpulan}

Modifikasi tapioka menjadi nanopartikel dan penambahan epiklorohidrin berpengaruh terhadap kemampuan swelling dan sifat fisik nanohidrogel. Tapioka yang berukuran nano menyebabkan tapioka lebih mudah mengalami pengikatan silang sehingga kekuatan fisik nanohidrogel yang dihasilkan semakin baik. Penambahan agen pengikat silang berupa epiklorohidrin menyebabkan penurunan nilai swelling namun meningkatkan kekuatan fisik nanohidrogel yang dihasilkan. Naohidrogel yang dihasilkan dari nanopartikel terhidrolisis 2 jam dengan penambahan epiklorohidrin sebesar $5 \%$ merupakan perlakuan yang paling baik dalam menghasilkan nanohidrogel pada penelitian ini.

\section{UCAPAN TERIMA KASIH}

Penelitian ini dapat terlaksana berkat pembiayaan oleh Badan Litbang Pertanian melalui kegiatan K4PS.

\section{DAFTAR PUSTAKA}

Ackar D, Babic J, Subaric D, Kopjar M, Milicevic B. 2010. Isolation of starch from two wheat varieties and their modification with epichlorohydrin. Carbohydrate Polymers. 81: $76-82$.

Annabi N, Mithieux SM, Weiss AS, Dehghani F. 2010. Crosslinked open pore elastic hydrogels based on tropoelastin, elastin and high pressure $\mathrm{CO}_{2}$. Biomaterials. 31: $1655-$ 1665.

Corre D, Bras J, dan Dufresne A. 2010. Starch nanoparticles: a review. Biomacromolecules. 11(1):1139 - 1153 .

Erizal, Abidin Z, Deswita, Sudirman. 2012. Superabsorben poli (akrilamida - ko - asam akrilat) - kitosan hasil iradiasi gamma untuk adsorpsi ion logam $\mathrm{Cu}^{2+}$ dan $\mathrm{Fe}^{3+}$. Indonesian
Journal of Materials Science. 12(3):168 174.

Erizal. Perkasa DP, Abbas B, Sulistioso GS. 2013. Sintesis kopolimer ikatan silang gelatin sisik ikan - kitosan mengunakan iradiasi gamma. Jurnal Ilmiah Aplikasi Isotop dan Radiasi. 9(2): $101-112$.

Faridah D, Fardiaz D, Andarwulan N, Sunarti T. 2010. Perubahan struktur pati garut (Maranta arundinaceae) sebagai akibat modifikasi hidrolisis asam, pemotongan titik percabangan dan siklus pemanasanpendinginan. J Teknol dan Indust Pangan. 21(2):135 - 142.

Ferrini LMK, Rochaa TS, dan Demiate IM, Franco CLM. 2008. Effect of acid methano treatment on the physicochemical and structural characteristics of cassava and maize starch. Starch/Starke. 60:417 - 425.

Garcia NL, Ribbon L, Dufresne A, Aranguren M, Goyanes S. 2011. Effect of glycerol on the morphology of nanocomposites made from thermoplastic starch and starch nanocrystals. Carbohydrate Polymers. 84(1): 203 - 210.

Ghanbarzadeh B, Almasi H, dan Entezami AA. 2011. Improving the barrier and mechanical properties of corn starch - based edible films : Effect of citrid acid and carboxymethyl cellulose. Industrial Crops and Products. 33:229- 235 .

Hurler J, Engesland A, Kermany BP, Basner NS. 2012. Improving texture analysis for hydrogel characterization gel cohesiveness, adhesiveness, and hardness. Journal of Applied Polymer Science. 125:180 - 188.

Kalhapure A, Kumar R, Singh VP, Pandey D. 2016. Hydrogels : a boon for increasing agricultural productivity in water - stressed environment. Current Science. General Articles. 111(11):1773 - 1779. 
Ma X, Jian R, Chang P, Yu J. 2008. Fabrication and characterization of citric acid - modified starch nanoparticles/plasticized - starch composites. Biomacromolecules. 9:3314 3320.

Miao M, Jiang B, Zhang T, Jin Z, Mu W. 2011. Impact of mild acid hydrolysis on structure and digestion properties of waxy maize starch. Food Chem. 126:506 - 513.

Kittipongpatana OS dan Kittipongpatana N. 2013. Physicochemical in vitro digestibility and functional properties of carboxymethyl rice starch cross-linked with epichlorohydrin. Food Chemistry. 141: 1438 - 1444.

Pudjiastuti I. 2010. Pengembangan proses inovatif kombinasi reaksi hidrolisis asam dan reaksi photokimia uv untuk produksi pati termodifikasi dari tapioka. [Tesis]. Semarang(ID):Universitas Diponegoro.

Srichuwong S, Sunarti TC, Takashi M, Naoto I, Makoto H. 2005. Starches from different botanical sources II: contribution of starch structure to swelling and pasting properties. Carbohydr Polym. 61(1):25-34.
Suwarda R dan Maarif M. 2013. Pengembangan inovasi teknologi nanopartikel berbasis pati untuk menciptakan produk yang berdaya saing. J Teknik Industri. 3(2):104 - 122.

Szymonska J, Korecka MT, dan Krok F. 2009. Characterization of starch nanoparticles. Journal of Physics : Conference Series. 146: $1-8$.

Winarti C, Sunarti TC, dan Richana N. 2011. Produksi dan aplikasi pati nanopartikel. Buletin Teknologi Pasca Panen. 7(2): 104 114.

Winarti C. 2014. Produksi pati garut nanopartikel sebagai matriks enkapsulasi bahan bioaktif herbal. [Disertasi]. Bogor (ID): Institut Pertanian Bogor.

Winarti C, Sunarti TC, Mangunwidjaya D, Richana N. 2014. Preparation of arrowroot starch nanoparticles by butanol - complex precipitation, and its application as bioactive encapsulation matrix. International Food Research Journal. 21(6):2207 - 2213. 